\title{
IMPLEMENTASI PENDIDIKAN AGAMA DI SEKOLAH MENENGAH KEJURUAN (SMK) BAKTI PANGKALPINANG BANGKA BELITUNG
}

\section{IMPLEMENTATION OF RELIGIOUS EDUCATION IN VOCATIONAL HIGH SCHOOL (SMK) BAKTI PANGKALPINANG BANGKA BELITUNG}

\author{
Qowaid \\ Puslitbang Pendidikan Agama dan Keagamaan \\ Badan Litbang dan Diklat Kementerian Agama RI \\ Email: qowaidbmasyhuri@gmail.com
}

Abstract

Religious education in schools must be given to students in accordance with the religion adopted and taught by teachers of the same religion. Religious education for children is also one form of implementation of human rights. Many schools have implemented in accordance with the rules. However, several schools, especially private schools, have not implemented religious education in schools in accordance with the regulations. This research is trying to know the implementation of religious education in private schools, in this case, Vocational High School Bakti Pangkalpinang Bangka Belitung. The results show that Buddhist, Christian, Catholic, Islamic, and Buddhist Education have been implemented in Bakti Vocational High School (SMK) Pangkalpinang according to the religion of the students. However, Confucian Religion Education has not been implemented in this School.

Keywords: Implementation, Religious Education, Human Rights.

\begin{abstract}
Abstrak
Pendidikan Agama di sekolah wajib diberikan kepada peserta didik sesuai dengan agama yang dianut dan diajar oleh guru yang seagama. Pendidikan agama bagi anak juga merupakan salah satu bentuk implementasi hak asasi manusia. Banyak sekolah telah mengimplementasikan sesuai dengan peraturan. Namun masihtidak sedikit sekolah, khususnya sekolah swasta, yang belum mengimplementasikan pendidikan agama di sekolah sesuai dengan ketentuan. Penelitian ini berusaha mengetahui implementasi pendidikan agama di sekolah swasta, dalam hal ini, Sekolah Menengah Kejuruan Bakti Pangkalpinang Bangka Belitung. Hasil penelitian menunjukkan bahwa Pendidikan Agama Buddha, Kristen, Katholik, Islam, dan telah diimplementasikan di Sekolah Menengah Kejuruan Bakti (SMK) Pangkalpinang sesuai agama yang dipeluk peserta didik. Adapun Pendidikan Agama Konghucu belum diimplementasikan di Sekolah ini.
\end{abstract}

Kata kunci: Implementasi, Pendidikan Agama, Hak Asasi Manusia. 


\section{PENDAHLUAN}

Pasal 31 ayat 3 Undang-Undang Dasar 1945 menyebutkan bahwa Pemerintah mengusahakan dan menyelenggarakan satu sistem pendidikan nasional, yang meningkatkan keimanan dan ketakwaan serta akhlak mulia dalam rangka mencerdaskan kehidupan bangsa. Selanjutnya disebutkan bahwa setiap warga negara berhak mendapat pendidikan, setiap warga negara wajib mengikuti pendidikan dasar dan pemerintah wajib membiayainya, pemerintah mengusahakan dan menyelenggarakan satu sistem pendidikan nasional, yang meningkatkan keimanan dan ketakwaan serta akhlak mulia dalam rangka mencerdaskan kehidupan bangsa. Di samping itu, negara memprioritaskan anggaran pendidikan sekurang-kurangnya dua puluh persen dari APBN serta APBD untuk memenuhi kebutuhan penyelenggaraan pendidikan nasional. ${ }^{1}$

Ini berarti bahwa cita-cita pembangunan nasional dalam bidang pendidikan adalah upaya mencerdaskan kehidupan bangsa dan meningkatkan kualitas manusia Indonesia yang beriman, bertakwa, dan berakhlak mulia, serta menguasai ilmu pengetahuan, teknologi, dan seni dalam mewujudkan masyarakat yang maju, adil, makmur, dan beradab berdasarkan Pancasila dan UndangUndang Negara Republik Indonesia Tahun 1945. Kualitas manusia Indonesia yang dibutuhkan oleh bangsa Indonesia pada masa depan adalah mampu menghadapi persaingan yang semakin ketat dengan bangsa lain di dunia. Kualitas manusia

1 Lihat: Undang-Undang Dasar Negara Republik Indonesia Tahun 1945, Bab XIII, Pasal 31 ayat 1, 2, 3, dan 4.
Indonesia tersebut antara lain dihasilkan melalui penyelenggaraan pendidikan yang bermutu.

Dalam konteks yang lebih luas, maka pendidikan di Indonesia merupakan bagian dari upaya mewujudkan cita-cita bangsa untuk mencerdaskan warga negara, menciptakan kesejahteraan umum, dan melaksanakanketertiban dunia sebagaimana tertuang dalam Preambul UUD 1945. Ikhtiar untuk mencerdaskan kehidupan bangsa dan menciptakan kesejahteraan umum dapat ditempuh antara lain melalui pendidikan, yang di dalam konstitusi dinyatakan sebagai salah satu bentuk hak asasi manusia yang harus dipenuhi negara.

Pendidikan memegang peranan penting dan strategis dalam pembangunan peradaban manusia. Maju mundurnya suatu masyarakat atau bangsa sangat dipengaruhi bahkan ditentukan oleh sejauhmana mutu penyelenggaraan dan hasil pendidikan itu sendiri. Begitu penting dan strategisnya pendidikan dalam konteks kehidupan berbangsa dan bernegara, maka perubahan dan perbaikan dengan segenap sistemnya perlu dilakukan secara terus menerus seiring kemajuan ilmu pengetahuan dan teknologi yang mengalami kecepatan dan percepatan luar biasa. Sejarah menunjukkan bahwa pendidikan memberikan manfaat bagi pencerdasan, pengadaban, dan kemajuan suatu bangsa.

Selanjutnya, dalam Pasal 12 ayat 1.a Undang-undang No 20 tahun 2003 tentang Sistem Pendidikan Nasional, disebutkan bahwa "Peserta didik pada setiap satuan pendidikan berhak mendapatkan pendidikan agama sesuai agama yang dianutnya". Bahkan 12 ayat 1.a. tersebut 
diberi penjelasan bahwa "pendidik dan atau guru agama yang seagama dengan peserta didik difasilitasi dan/atau disediakan oleh Pemerintah atau pemerintah daerah sesuai kebutuhan satuan pendidikan sebagaimana diatur dalam Pasal 41 ayat (3)".

Salah satu kurikulum yang wajib dimuat dalam dunia pendidikan kita, mulai dari pendidikan tingkat dasar, menengah, sampai tingkat tinggi adalah pendidikan agama. Pendidikan Agama, dalam berbagai tingkatan tersebut, termasuk Pendidikan Agama di sekolah memiliki posisi penting dalam proses pendidikan di sekolah, baik dilihat dari landasan yuridis maupun dilihat peran strategisnya di masyarakat kita. Pendidikan Agama pada Sekolah saat ini juga telah mengalami perkembangan yang pesat bila dibandingkan waktu sebelumnya.

Sebagai tindak lanjutnya dikeluarkanlah Peraturan Pemerintah Nomor 55 Tahun 2007 tentang Pendidikan Agama dan Keagamaan. Dalam Pasal 3 PP tersebut antara lain disebutkan bahwa setiap satuan pendidikan pada semua jalur, jenjang, dan jenis pendidikan wajib menyelenggarakan pendidikan agama. Setiap peserta didik pada satuan pendidikan di semua jalur, jenjang, dan jenis pendidikan berhak mendapat pendidikan agama sesuai agama yang dianutnya dan diajar oleh pendidik yang seagama. Pengelolaan pendidikan agama dilaksanakan oleh Menteri Agama.

Oleh karena itu, adalah wajar apabila posisi Pendidikan Agama di Sekolah saat ini, khususnya Agama Islam, telah mengalami kemajuan yang signifikan bila dibandingkan dengan masa-masa sebelumnya, mulai dari masa penjajahan Belanda, penjajahan Jepang, awal kemerdekaan, masa orde lama, orde baru, dan orde reformasi ini. Urusan Pendidikan Agama pada Sekolah, sejak awal Kementerian Agama berdiri pada tanggal 3 Januari 1946 sampai saat ini, selalu di bawah urusan Kementerian Agama Republik Indonesia. $^{2}$

Terlihat betapa secara juridis formal, pendidikan agama secara bertahap semakin mendapatkan posisi yang kuat dalam lanskap sistem pendidikan nasional kita. Namun demikian, secara faktual, implementasi dan hasil pendidikan agama yang telah dilakukan di sekolah dianggap belum optimal atau belum mencapai tujuan seperti yang diharapkan. Walaupun posisi Pendidikan Agama pada Sekolah demikian kuat, masih terdengar adanya sorotan atau kritikan masyarakat terhadap implementasi dan implikasinya pada kehidupan sosial di sekitarnya.

Secara sosiologis, tuntutan untuk terlaksananya pendidikan pada umumnya dan pendidikan agama pada khususnya sangat reliastis. Masyarakat Indonesia dikenal sebagai masyarakat yang beragama (religious). Berbagai agama dianut dan dikembangkan dengan antusias oleh masyarakat.

Sebagai implementasinya, sampai saat ini, Pemerintah beserta masyarakat telah banyak berupaya agar Pendidikan Agama di sekolah terlaksana dengan baik. Berbagai capaian positif telah dirasakan, walaupun harus diakui bahwa pelaksanaan Pendidikan

2 Lihat antara lain: Tim Penyusun. 1996. Departemen Agama Dari Masa Ke Masa Dalam Kurun Setengah Abad. Jakarta: Badan Litbang Agama. h. 33 - 34. Abdurrahman Shaleh. 1999. Aktualisasi Politik Pendidikan di Lingkungan Departemen Agama. Jakarta: Badan Litbang Agama, h. 11-12. 
Agama di Sekolah belum mencapai kualitas yang diharapkan.

Namun demikian, sampai saat ini, masih terdapat sejumlah kritik terhadap pembelajaran Pendidikan Agama, termasuk Pendidikan Agama Islam. Berbagai kelompok masyarakat menyoroti atau mengkritik implementasi pendidikan agama di sekolah dan implikasinya pada kehidupan sosial di sekitarnya. Pendidikan agama di sekolah-sekolah masih belum berhasil secara maksimal, kalau tidak dikatakan telah gagal mencapai tujuan pendidikan agama. ${ }^{3}$ Rendahnya kualitas keberagamaan tersebut berkait erat dengan pendidikan agama di semua jenjang yang dinilai belum optimal bagi pengembangan pribadi, watak, dan akhlak mulia peserta didik. ${ }^{4}$ Dalam hal Pendidikan AgamaIslammisalnya,Direktorat PAIS sendiri telah menginventarissasi sejumlah kekurangan dan telah, sedang serta terus melakukan perbaikan, baik pada tataran landasan berupa peraturan maupun lingkup operasionalnya. ${ }^{5}$

Di sejumlah daerah Pendidikan Agama di Sekolah telah dilaksanakan sesuai dengan peraturan atau ketentuan yang ada, khususnya pada berbagai jenjang dan jenis sekolah negeri. Akan tetapi di sejumlah sekolah swasta, pendidikan agama belum

${ }^{3}$ Lihat antara lain: pendapat K.H. Sahal Mahfudz, Harian Kompas. 2003. "Pendidikan Agama di Sekolah Dinilai Gagal”. 31 Mei 2003.

${ }^{4}$ Direktur Jenderal Kelembagaan Agama Islam. 2002. Buku Kebijakan Direktur Jenderal Kelembagaan Agama Islam di Bidang Pendidikan Agama dan Keagamaan Islam. Jakarta: Direktur Jenderal Kelembagaan Agama Islam, h.11.

${ }^{5}$. Imam Tholkhah. 2010.Rencana Strategis Direktorat Pendidikan Agama Islam Pada Sekolah Tahun 2010 - 2014. Jakarta:Direktorat Jenderal Pendidikan Islam Kementerian Agama RI., h. 4-5. dilaksanakan atau diterapkan sesuai dengan ketentuan atau peraturan yang ada, dengan alasan yang beraneka ragam. Oleh karena itu perlu dilakukan yang lebih banyak lagi penelitian untuk mengetahui implementasi pendidikan agama di sekolah dengan berbagai alasan yang ada.

Masalahnya adalah bagaimanakah sebaran peserta didik berdasar agama pada SMK Bakti Pangkalpinang? Bagaimanakah pelaksanaan Pendidikan Agama di sekolah swasta, dalam hal ini di Sekolah Menengah Kejuruan Bakti di Pangkalpinang Bangka Belitung? Pendidikan Agama sajakah yang telah dilaksanakan di SMK Bakti tersebut?

Oleh karena itu, tujuan penelitian ini adalah: 1) mengetahui sebaran peserta didik dan guru berdasar agama pada SMK Bakti Pangkalpinang; 2) mengetahui Pendidikan Agama yang telah diimplementasikan di sekolah swasta, dalam hal ini di Sekolah Menegah Kejuruan Bakti di Pangkalpinang Bangka Belitung, beserta bentuk dan isi implementasinya, sesuai agama yang dipeluk peserta didik; 3) mengetahui Pendidikan Agama yang belum diimplementasikan di SMK Bakti ini sesuai agama yang dipeluk peserta didik dan sebab belum terimplementasikannya, dan 4) mengetahui faktor pendukung dan penghambat implementasi Pendidikan Agama di SMK Bakti Kota Pangkalpinang..

\section{Kajian Terdahulu}

Sampai saat ini telah beberapa kali dilakukan penelitian dan pengkajian terhadap pelaksanaan Pendidikan Agama di sekolah, khususnya swasta. Berikut disajikan sebagian hasil penelitian mengenai Pendidikan Agama di sekolah. 
Nurudin menulis bahwa terdapat sekolah Katolik di Blitar yang belum melaksanakan amanat Undang-Undang Sisdiknas Pasal 12 ayat 1 poin a dan PP No. 55 tahun 2007, dimana peserta didik pada lembaga pendidikan tersebut belum mendapatkan pendidikan agama sesuai agama yang dianutnya. Walaupun Pemerintah Kota Blitar telah mendistribusikan guru-guru beragama Kristen, Islam, Hindu, dan Buddha kepada sekolah yang bersangkutan untuk menjalankan agama pendidikan agama sesuai dengan agama siswa, para Kapala Sekolah Katolik tersebut menangguhkan pelaksanaan pendidikan agama sebagaimana amanat Undang-Undang. ${ }^{6}$

Iman Tholkhah juga menulis tentang sekolah swasta, yakni SMA Muhammadiyah di Kupang Nusa Tenggara Timur. Kebijakan SMA Muhammadiyah berbeda dengan kebijakan di sekolah Katolik Blitar. Apabila para siswa non Katolik di sekolah Katolik Blitar tidak diajarkan pendidikan agama sesuai dengan agama siswanya, dan seluruh siswa diberikan pendidikan agama Katolik, maka SMA Muhammadiyah Kupang memberikan Pendidikan Agama sesuai dengan agama yang dipeluk oleh siswa dan diajarkan oleh guru yang segama dengan siswa. ${ }^{7}$

Sementara itu, Center for Religious \& Cross-cultural Studies (CRCS) mengkritisi mengenai pendidikan agama di sekolah.

6 Nurudin. 2013. “Implementasi Kebijakan Pendidikan Agama Di Sekolah-Sekolah Katolik. Studi Kasus Kota Blitar Provinsi Jawa Timur". Edukasi. Jurnal Pendidikan Agama dan Keagamaan, 2013 (3), h. 189.

${ }^{7}$ Imam Tholkhah. 2013. "Pendidikan Toleransi Keagamaan: Studi Kasus SMA Muhammadiyah Kupang Nusa Tenggara Timur". Edukasi. Jurnal Pendidikan Agama dan Keagamaan, 2013 (3), h. 174.
Dalam dunia pendidikan, "agama” telah menjadi "index siswa". Index disini diartikan sebagai "penunjuk" yang turut melekat pada identitas siswa. Siswa harus mengidentifikasiagama dirinya denganjelas. Pendidikan agama yang mengasumsikan adanya identitas tegas yang memisahkan siswa berdasarkan agama-agama akan menimbulkan masalah karena tidak bisa mengakomodasi keragaman keagamaan siswa secara memadai, termasuk keragaman di dalam setiap agama itu sendiri. ${ }^{8}$

Di lain pihak Haidar Bagir cendekiawan muslim, pendiri sekolah Lazuardi- menyatakan bahwa pendidikan agama kita telah gagal. Agama diperlakukan sebagai kumpulan simbol-simbol yang harus diajarkan kepada anak didik dan diulangulang, tanpa memikirkan korelasi antara simbol-simbol ini dengan kenyataan dan aktivitas kehidupan di sekeliling mereka. Dalam hal pemikiran, para siswa/siswi kerap dibombardir dengan serangkaian norma legalistik berdasarkan aturan-aturan fikih yang telah kehilangan ruh moralnya. Proses pendidikan yang baik harus menggarap sekaligus ketiga ranah tersebut. Haidar mengemukakan dua aspek yang menjadi sebab utama gagalnya pendidikan agama Indonesia. Pertama, karena pendidikan agama selama ini masih berpusat pada hal-hal yang bersifat simbolik, ritualistik dan legal-formalistik. Kedua, pendidikan agama di Indonesia dinilai gagal karena mengabaikan syarat-syarat dasar pendidikan yang mencakup tiga ranah kognitif,

\footnotetext{
${ }^{8}$ Suhadi dkk. 2014. Politik Pendidikan Agama, Kurikulum 2013, dan ruang Publik Sekolah. Yogyakarta: Center for Religious \& Cross-cultural Studies (CRCS). Sekolah Pascasarjana, Universitas Gadjah Mada, h. 15.
} 
afektif dan psikomotorik. Menurut Haidar, pendidikan agama selama ini cenderung bertumpu pada penggarapan ranah kognitif atau paling banter hingga ranah afektif, dan cenderung mengabaikan aras psikomotorik. Itulah sebabnya, Haidar berpendapat bahwa untuk menilai pendidikan agama di sekolah tidak boleh didasarkan melulu pada hasil tes tertulis -agar tak tinggal hanya sebagai kesadaran kognitif atau afektif saja- tetapi harus dikaitkan dengan kemajuan, disiplin, dan kontinuitas dalam menerapkan nilainilai etika personal dan sosial dalam praktik. ${ }^{9}$

\section{Landasan Konseptual}

Konsep utama dari penelitian ini pendidikan agama di sekolah dan implementasinya. Untuk memperkuat pentingnya pendidikan agama sesuai agama peserta didik atau siswa, disajikan pula posisi pendidikan agama dalam konteks hak asasi manusia.

Pendidikan Agama di sekolah merupakan bagian dari sistem pendidikan nasional yang telah dibuat sejumlah aturan mulai dari Undang-undang, Peraturan Pemerintah, Peraturan Menteri, sampai Peraturan di bawahnya. Pada dasarnya pendidikan adalah usaha untuk merubah orang melalui pengajaran atau pelatihan agar menjadi manusia yang lebih sempurna/ baik. Secara lebih jelas disebutkan dalam Undang-Undang Sistem Pendidikan Nasional Nomor 20 tahun 2003, Pasal 1 ayat 1 bahwa pendidikan adalah usaha sadar dan terencana untuk mewujudkan suasana belajar dan proses pembelajaran agar

${ }^{9}$ Haidar Bagir. 2003. "Gagalnya Pendidikan Agama", Harian Kompas, Jum’at 28 Februari 2003. peserta didik secara aktif mengembangkan potensi dirinya untuk memiliki kekuatan spiritual keagamaan, pengendalian diri, kepribadian, kecerdasan, akhlak mulia, serta keterampilan yang diperlukan dirinya, masyarakat, bangsa dan negara. ${ }^{10}$

Adapun Pendidikan Agama di Sekolah adalah pendidikan yang memberikan pengetahuan dan membentuk sikap, kepribadian dan keterampilan peserta didik dalam mengamalkan ajaran agama, yang dilaksanakan sekurang-kurangnya melalui mata pelajaran pada semua jalur, jenjang, dan jenis pendidikan. ${ }^{11}$

Pendidikan Agama di SMK berbentuk proses pembelajaran di sekolah baik yang intra maupun yang ekstrakurikuler. Keberhasilan pembelajaran dapat diartikan sebagai suatu hasil yang dicapai setelah melakukan proses atau aktifitas belajar. Menurut Sudjana, keberhasilan belajar adalah perubahan tingkah laku sebagai hasil belajar yang mencakup bidang kognitif, afektif, dan psikomotorik. ${ }^{12}$

Secara lebih sepesifik, pembelajaran dikatakan berhasil apabila tujuan khusus pembelajaran tercapai. Dikaitkan dengan topik ini, maka yang dimaksud dengan pelaksanaan keberhasilan Pendidikan Agama di SMK adalah adanya pembelajaran Pendidikan Agama di SMK pada aspek pengetahuan, sikap dan keterampilan ( kognitif, afektif, dan psikomotorik).

${ }^{10}$ Undang-Undang Sistem Pendidikan Nasional Nomor 20 tahun 2003, Pasal 1 ayat 1.

${ }^{11}$ Peraturan Pemerintah Nomor 55 Tahun 2007 tentang Pendidikan Agama dan Keagamaan, Pasal 1 ayat 1.

${ }^{12}$ Nan Sudjana. 1989. Penilaian Hasil Proses Belajar Mengajar. Bandung. Remaja Rosdakarya, h. 4. 
Untuk mempertegas aturan tersebut, maka Kementerian Agama RI mengeluarkan Keputusan Menteri Agama Nomor 6 Tahun 2010 tentang Pengelolalaan Pendidikan Agama pada Sekolah. Pada Pasal 3, secara eksplisit dinyatakan bahwa setiap sekolah berkewajiban menyediakan pelajaran agama kepada siswa, dan diajarkan oleh guru yang seagama dengan siswa. Selanjutnya dalam Pasal 4 dinyatakan ketentuan teknis tentang pelajaran agama di kelas atau sekolah, sebagai berikut: (1) Dalam hal jumlah peserta didik yang seagama dalam satu kelas paling sedikit 15 (lima belas) orang wajib diberikan pendidikan agama kepada peserta didik di kelas; (2) Dalam hal jumlah peserta didik yang seagama dalam satu kelas kurang dari 15 (lima belas) orang, tetapi dengan cara penggabungan beberapa kelas paralel mencapai paling sedikit 15 (lima belas) orang, maka pendidikan agama pada sekolah dilaksanakan dengan mengatur jadwal tersendiri yang tidak merugikan siswa untuk mengikuti mata pelajaran lain; (3) Dalam hal jumlah peserta didik yang seagama pada sekolah paling sedikit 15 (lima belas) orang, maka pendidikan agama wajib dilaksanakan di sekolah tersebut; (4) Dalam jumlah peserta didik yang seagama pada satu sekolah kurang dari 15 (lima belas) orang, maka pendidikan agama dilaksanakan bekerja sama dengan sekolah lain, atau lembaga keagamaan yang ada di wilayahnya. ${ }^{13}$

Pendidikan agama yang wajib diberikan kepada peserta didik sesuai agamanya juga tidak bertentangan dengan hak asasi

13 Lihat: Keputusan Menteri Agama Nomor 6 Tahun 2010 tentang Pengelolalaan Pendidikan Agama pada Sekolah. Pada Pasal 3 dan 4. manusia dalam beragama. Kebebasan beragama merupakan salah satu hak dasar yang melekat pada setiap orang. Dalam deklarasi Universal tentang HAM yang diadopsi PBB tahun 1948, pasal 18, 26, dan 29 disebutkan mengenai pokok-pokok kebebasan beragama itu. Pasal 18 misalnya mengatakan bahwa setiap orang mempunyai hak kebebasan berpikir, berkesadaran, dan beragama, termasuk kebebasan memilih dan memeluk agama, dan menyatakan agamanya itu dalam pengajaran, pengamalan, dan beribadatnya, baik secara sendiri-sendiri maupun dalam kelompok. ${ }^{14}$

Kemudian dalam Kovenan Internasional tentang Hak-hak Ekonomi, Sosial, dan Budaya yang disahkan PBB tanggal 16 Desember 1966, pada pasal 13 ayat 3 antara lain dinyatakan bahwa bahwa semua negara yang meratifikasi konvenan tersebut harus menghormati kebebasan orang tua dan wali untuk memastikan bahwa pendidikan agama dan moral anak-anak sesuai dengan keyakinan mereka. ${ }^{15}$

Pemerintah Indonesia Indonesia telah meratifikasi lewat UU No. 12 tahun 2005 tentang Pengesahan Konvenan Internasional tentang Hak-hak Sipil dan Politik. Itu berarti bahwa ketentuan dalam deklarasi tersebut diakui dan berlaku secara mengikat di wilayah NKRI.

Selanjutnya ketentuan tersebut diperkuat melalui Undang-Undang Perlindungan Anak Nomor 23 Tahun 2002 yang menyatakan : (1) setiap anak

${ }^{14}$ Lihat: Deklarasi Universal Hak Asasi Manusia. Diterima dan diumumkan oleh Majlis Umum PBB, tanggal 10 Desember 1948.

15 Lihat: Kovenan Internasional Hak-hak Ekonomi, Sosial, Budaya. Ditetapkan oleh Resolusi Majlis Umum PBB tertanggal 16 Desember 1966. 
mendapat perlindungan untuk beribadah menurut agamanya, (2) Sebelum anak dapat menentukan pilihannya, agama yang dipeluk anak mengikuti agama orang tuanya. Negara, pemerintah, masyarakat, keluarga, orang tua, wali, dan lembaga sosial menjamin perlindungan anak dalam memeluk agamanya, perlindungan anak dalam memeluk agamanya sebagaimana dimaksud meliputi pembinaan, pembimbingan, dan pengamalan ajaran agama bagi anak. ${ }^{16}$

Adapun implemetansi menurut menurut A.S. Hornby dkk. Berasal dari kata implement yakni carry (undertaking, agreement, promise) intoeffect, ${ }^{17}$ yangdapatdiartikansebagai usaha untuk memberlakukan atau melaksanakan. Kebijakan pendidikan merupakan bagian dari kebijakan publik, yakni kebijakan di bidang pendidikan, untuk mencapai tujuan pembangunan negara-bangsa di bidang pendidikan, sebagai salah satu bagian dari tujuan pembangunan negara bangsa secara keseluruhan. ${ }^{18}$ Tolok ukur keberhasilan kebijakan pendidikan dapat dilihat pada bagaimana implementasinya. Rumusan kebijakan yang dibuat bukan hanya sekedar berhenti pada tataran rumusan, melainkan secara fungsional dilaksanakan. Sebaik apapun rumusan kebijakan yang dibuat, jika tidak diimplementasikan, tidak akan dapat dirasakan manfaatnya. Sebaliknya, sesederhana apa pun rumusan kebijakan,

16 Lihat: Undang-Undang Perlindungan Anak Nomor 23 Tahun 2002.

17 A.S. Horby, dkk. 1972. The Advance Learner's Dictionary of Current English. London: Oxford University Press. Seventh Impression, h. 492.

${ }^{18}$ Riant Nugroho, 2013. Kebijakan Pendidikan Yang Unggul. Cetakan ke II. Yogyakarta: Pustaka Pelajar, h. 37. jika sudah diimplementasikan, akan lebih bermanfaat, apa pun hasilnya. ${ }^{19}$

Metodologi analisis kebijakan dipaandang sebagai proses pengkajian yang dirancang untuk menemukan solusi secara praktis, ${ }^{20}$ yang mengacu pada suatu proses penyelidikan untuk mencari solusi yang tepat. Implementasi biasanya dikaitkan dengan kebijakan tertentu, dalam hal ini adalah kebijakan dalam Pendidikan Agama. Oleh karena itu, dalam kaitan ini adalah pelaksanaan atau penerapan kebijakan pendidikan agama di SMK Bakti.

\section{METODOLOFI PENELITIAN}

Secara metodologis, penelitian ini menggunakan pendekatan kualitatif. Teknik pengumpulan data dilakukan dengan menggunakan studi dokumen, wawancara, dan observasi. Lokasi penelitian ini adalah SMK Bakti Kota Pangkalpinang Provinsi Bangka Belitung. Pemilihan lokasi tersebut adalah dengan mempertimbangkan keberadaan siswa berdasar agama yang cukup variatif.

\section{HASIL DAN PEMBAHASAN}

\section{Profil SMK Bakti Kota Pangkalpinang Bangka Belitung}

Sekolah Menengah Kejuruan Bakti beralamat di Jalan Bintang No. 10, Kelurahan Bintang, Kecamatan Rangkui, Kota Pangkalpinang, Provinsi Kepulauan Bangka Belitung. Lokasi ini termasuk

${ }^{19}$ M. Hasbullah, 2015. Kebijakan Pendidikan Dalam Perspektif Teori, Aplikasi, dan Kondisi Objektif Pendidikan di Inndonesia. Jakarta: PT Rajagrafindo, h. 91.

20 Nanang Fatah. 2014. Analisis Kebijakan Pendidikan. Bandung: PT Remaja Rosdakarya, h. 5. 
wilayah "pecinan", sekeliling kompleks sekolah dihuni umumnya berasal dari etnis Tionghoa. Di samping tempat hunian, di daerah ini terdapat banyak bangunan untuk pertokoan yang digunakan untuk usaha dagang. Banyak pula gedung berlantai, umumnya lantai tiga atau empat, yang dimanfaatkan untuk memelihara sarang bulung walet.

SMK Bakti merupakan sekolah swasta berada di bawah naungan Yayasan Bakti Bangka. Yayasan ini berdiri pada tanggal 28 Oktober 1995. Pendirinya adalah Totong Siabini dan isterinya Melvina Rusli. Susunan pengurus Yayasan ada yang sudah terisi dan ada yang belum terisi. Susunan yang telah terisi adalah Ketua Yayasan bernama Totong Siabini SE, Sekretaris Yayasan bernama Semijati Siabini, dan bendaharanya adalah Melvina Rusli SE. Semuanya adalah keluarga pengusaha terutama usaha air minum dalam botol, lada, kelapa sawit dan lain sebagainya. Adapun Pembina, wakil ketua dan berbagai bidang belum terisi.

Tahun berikutnya, yakni pertengahan tahun 1996, didirikanlah Sekolah Menengah Kejuruan Bakti. Jurusannya difokuskan pada hal yang terkait dengan ekonomi. Atau dengan isitilah yang dulu sering dipakai adalah Sekolah Menengah Ekonomi Atas. Alasan pendiriannya antara lain dimaksudkan untuk menampung siswa lulusanSMPsederajatyanginginmelanjutkan ke sekolah kejuruan, bukan ke menengah umum seperti SMA. Saat itu peminat yang ingin masuk SMK cukup banyak, antara lain ditandai oleh membludaknya calon peserta didik yang ingin masuk ke berbagai SMK, baik SMK Negeri maupun swasta. Banyak mereka yang tidak dapat tertampung, khususnya dari etnis Tionghoa yang tingkat ekonominya tergolong menengah ke bawah. Akhirnya didirikanlah SMK Bakti untuk menampung calon peserta didik yang cukup banyak, disamping juga untuk mewujudkan cita-citanya.

Pemilihan jurusan yang terkait dengan ekonomi tersebut tidak terlepas dari aktifitas pengelola Yayasan sebelumnya. Para pengelola Yayasan ini sudah lama bergerak di bidang pendidikan nonformal berupa menyelenggarakan kursus akuntasi dan Bahasa Inggris. Sebelum didirikankan SMK ini, Pimpinan Yayasan sering bertemu dengan Pimpinan SMKN 1 Pangkalpinang dan para pengajar kursus tersebut seperti Yanuar Teriman B. Sc. Dalam pertemuan tersebut dibahas pentingnya mendirikan SMK sebagai pengembangan dari kursus yang sudah ada, di samping untuk menampung calon siswa yang ingin belajar di SMK. Akhirnya disepakati pendirian SMK Bakti.

Sebelum didirikan, terlebih dahulu disiapkan sejumlah pendukungnya. Di antaranya pendirian Akta Yayasan, Tim Pendiri, biaya awal, pembuatan ruang kelas dan lain sebagainya. Setelah dianggap cukup, maka didirikanlah sekolah ini pada tahun 1996, dengan membuka tiga ruang kelas. Dengan demikian, pendidirian SMK ini sesungguhnya telah dilatarbelakangi oleh bentuk kegiatan dan keterlibatan yang tidak jauh beda dengan SMK tersebut.

Ditunjuk sebagai Kepala sekolah pertama kali adalah Bapak Humaidi, yang saat itu masih menjabat sebagai Wakil Kepala Sekolah SMKN 1 Pangkalpinang. Humaidi menjabat selama 8 tahun yakni mulai tahun 1996 sampai 2003. Setelah itu, Kepala Sekolah dijabat oleh Yanuar 
Teriman B. Sc, mulai 2003 sampai 2013. Kepala Sekolah selanjutnya dijabat oleh Hastin Lusiana Todhasi SE. yang dijabat sejak tahu 2013 sampai sekarang. Hastin adalah wanita kelahiran Wonosobo tahun 1973, dan tamat S1 Jurusan Ekonomi Studi Pembangunan salah satu perguruan tinggi di Yogyakarta. Adapun program keahliannya yang dibuka saat ini ada tiga yakni Akuntasi (AK), Penjualan (PJ), dan Multimedia (MM).

Dalam struktur organisasi SMK Bakti ini, Kepala Sekolah dibantu oleh Wakasek Bidang Humas/Sarpras yakni Izwar Ramadhan, SE; Wakasek Bidang Kurikulum yakni Empi Natal Adha, S. Ag; Wakasek Bidang Kesiswaan Erma Susanti. S. Si; Para Kajur, dan Kasubag TU. Saat ini, SMK Bakti mengembangkan bidang keahlian bisnis dan manajemen. SMK Bakti merupakan satu dari 9 SMK yang ada di Kota Pangkalpinang. Delapan SMK lainnya adalah SMKN 1, SMKN 2,SMKN 3, SMKN 4, SMKN 5, SMK PGRI, SMK SORE, dan SMK TUNAS KARYA. Dengan demikian, SMK Bakti merupakan salah satu dari 4 SMK swasta.

Visi sekolah ini adalah: menjadikan lembaga pendidikan dan pelatihan yang menghasilkan sumber daya manusia yang handal dan berwawasan luas. Adapun misinya adalah: a) Mengembangkan mutu dan kualitas pendidikan dengan melibatkan dunia usaha/industri, instansi terkait dan masyarakat; b) Mengoptimalkan sumber daya sekolah untuk memberikan layanan kepada dunia usaha,dunia industri, instansi terkait dan masyarakat; c) Meningkatkan kemampuan berkomunikasi global seluruh elemen sekolah dengan tetap menjunjung tinggi norma dan nilai budaya Bangsa Indonesia; d) Menghasilkan tamatan yang memiliki kompetensi sesuai dengan bidang keahliannya, memiliki daya adaptasi dan daya saing tinggi.

Berkaitan dengan siswa atau peserta didik, berikut ini disajikan jumlah siswa dan jumlah rombongan belajarnya, serta ujian sekolah dan tingkat kelulusannya. Di samping itu disajikan ringkas mengenai sarana parsarana.

Seluruh siswa saat ini berjumlah 657 orang, terdiri dari 299 laki-laki dan 358 perempuan. Jumlah murid SMK Bakti sebanyak itu ternyata menempati posisi murid paling banyak di antara sesama SMK swasta dan menempati urutan ketiga dari segi jumlah murid di antara seluruh SMK negeri dan Swasta di Pangkalpinang. Sejak tahun 2008, jumlah siswa SMK Bakti selalu lebih dari 600 orang. Bahkan pada tahun 2007 siswanya mencapai lebih dari 700 orang. Hal ini menunjukkan bahwa jumlah siswa SMK Bakti dalam beberapa tahun ini tergolong banyak dan stabil. Dari segi jenis kelamin, jumlah peserta didik perempuan selalu lebih banyak dari yang laki-laki. Namun jaraknya dalam beberapa tahun tersebut tidak terlalu banyak, tidak lebih dari 50 peserta didik. Dengan demikian, sekolah ini selalu banyak diminati oleh masyarakat Pangkalpinang baik yang laki-laki maupun perempuan.

Rombongan belajar masing-masing kelas dari tahun ke tahun jumlahnya juga stabil. Sejak tahun 2007 sampai 2015 ini jumlah rombongan belajar SMK Bakti selalu 15 rombongan belajar, terdiri dari 5 rombongan belajar untuk masing-masing kelas X, XI, dan XII. Jumlah rombongan belajar sangat terkait dengan ketersediaan ruang dan jumlah peserta didik. Memang sudah lebih dari 5 tahun sekolah ini tidak mengalami penambahan ruang kelas. 
Perubahannya hanya merehabilitasi kelas dan fasilitas yang ada. Walaupun peminat selalu melebihi rencana penerimaan peserta didik, pihak sekolah tidak dapat menambah jumlahnya secara signifikan karena keterbatasan ruang kelas.

Peserta ujian dalam beberapa tahun jumlahnya selalu di atas 200 siswa. Hal itu berkaitan dengan jumlah peserta didik di kelas XII pada masing-masing jurusan. Tingkat kelulusannyapun tergolong sangat tinggi, selalu di atas $95 \%$. Bahkan pada tahun 2013 yang lulu tingkat kelulusannya mencapai 100\%. Dari tahun ke tahun, sejalan dengan jumlah peserta didik dari segi jenis kelamin, maka peserta didik perempuan yang mengikuti ujian juga lebih banyak dari pada laki-laki.

Nilai ujian yang ada mencakup nilai ujian mata pelajaran Bahasa Indonesia, Bahasa Inggris, Matematika dan Kompetensi Kejuruan. Sejak tahun 2007, ternyata nilai rata-rata Kompetensi Kejuruan umumnya berada di posisi paling tinggi dibandingkan dengan nilai yang lainnya. Sementara itu, nilai Bahasa Inggris berada di posisi paling rendah.

SMK Bakti Pangkalpinang saat ini telah memiliki sejumlah fasilitas berupa ruangan untuk berbagai keperluan. Kondisi ruangan umumnya baik. Hanya sedikit yang tergolong rusak ringan. Yang tergolong kondisinya masih baik antara lain ruang kelas, ruang Kepala Sekolah, ruang Perpustakaan, Ruang UKS, ruang BK, ruang laboratorium komputer, akuntasi, unit produksi, dan ruang ibadah. Yang tergolong kuang baik (rusak ringan) antara lain ruang guru, gudang dan WC. Lapangan Olahraga seluas $90 \mathrm{~m} 2$.

\section{Implementasi Pendidikan Agama di SMK Bakti}

Sebelum diuraikan implementasi pendidikan agama pada SMK Bakti Pangkalpinang, berikut disajikan terlebih dahulu data peserta didik dan tenaga kependidikan berdasar agama yang dipeluk mereka.

Tabel 1

Pemeluk Agama Peserta Didik SMK Bakti Pangkalpinang

\begin{tabular}{cccccccc}
\hline & \multicolumn{7}{c}{ Pemeluk Agama Peserta Didik } \\
\cline { 2 - 8 } Kelas & Islam & Katolik & Kristen & Buddha & Konghucu & Hindu & Jumlah \\
\hline I & 14 & 40 & 47 & 86 & 43 & 1 & 231 \\
\hline II & 37 & 37 & 38 & 72 & 43 & 0 & 227 \\
\hline III & 25 & 26 & 26 & 29 & 75 & 0 & 199 \\
\hline Jumlah & 76 & 103 & 114 & 233 & 130 & 1 & 657 \\
\hline
\end{tabular}

Tabel di atas memperlihatkan bahwa peserta didik tahun 2015 yang berjumlah 657 orang, (terdiri dari 299 laki-laki dan 358 perempuan). Mereka memeluk salah satu dari 6 (enam) agama yang ada, yakni sebagian memeluk agama Islam, Kristen, Katholik, Hindu, Buddha dan Konghucu. Hanya jumlahnya yang tidak sama. Pemeluk agama Islam berjumlah 76 orang (11,56\%) terdiri dari 26 laki-laki dan 50 perempuan. Pemeluk agama Kristen berjumlah 114 orang (17,35\%), terdiri dari 45 laki-laki dan 69 perempuan. Pemeluk agama Katholik berjumlah 103 orang (15,68\%), terdiri dari 50 laki-laki dan 53 perempuan. Pemeluk agama Hindu satu orang $(0,15 \%)$, terdiri dari lakilaki dan perempuan. Pemeluk agama Buddha berjumlah 233 orang $(35,46 \%)$, terdiri dari 119 laki-laki dan 114 perempuan. Pemeluk agama Konghucu berjumlah 130 (19,79 \%), terdiri dari 58 laki-laki dan 72 perempuan.

Dengan demikian agama Buddha dipeluk paling banyak oleh siswa SMK Bakti. Selanjutnya secara berurutan mereka 
memeluk agama Kristen, Katolik, Konghucu, agama Islam, dan agama Hindu.

Tenaga Pendidik dan tenaga kependidikan saat ini berjumlah 47 orang. Dari segi agama, sebagian besar memeluk agama Islam yakni berjumlah 33 orang (70 \%), agama Katholik sebanyak 5 orang. Pemeluk agama Kristen, Buddha, dan Konghucu masing-masing berjumlah oleh 3 orang.

Jumlah guru pendidikan agama di sekolah ini tergolong banyak, yakni 11 orang, terdiri dari 2 guru pendidikan agama Islam, dan masing-masing 3 guru pendidikan agama Kristen, guru pendidikan agama Katholik, serta guru pendidikan agama Buddha. Tidak terdapat guru pendidikan agama Hindu dan Konghucu di sekolah ini.

Pendidikan Agama Islam di SMK Bakti diajar atau dilayani oleh dua orang GPAI yang semuanya laki-laki, yakni Drs. Ibrahim Sani dan Rachmadi S. Ag. Keduanya tamatan IAIN Raden Patah Palembang (S1). Saat ini Ibrahim berusia 53 tahun, dan Racmadi 36 tahun. Ibrahim yang mengajar sejak berdirinya SMK ini (1996), telah mendapat sertifikasi guru. Ia juga hanya mengajar di SMK ini, dan satu-satunya guru Pendidikan Agama yang menjadi Guru Tatap Yayasan (GTY). Racmadi telah mengajar di SMK ini selama 5 tahun, belum mendapat sertifikasi guru, mengajar juga di tempat lain, serta menjadi pegawai tidak tetap yayasan (GTTY). Dengan demikian, Ibrahim Sani tergolong guru yang telah banyak pengalaman dan lebih mampu secara teoritis berkonsentrasi mengajar di SMK Bakti.

Guru Pendidikan Agama Kristen di sekolah ini berjumlah tiga orang yakni Hanung Sri Hartanto S. Pd. K, Darwin Purba
S. Pd., dan Jerlina Pakpahan S. Pd. K. Hanung lulusan S1 Pendidikan Agama Kristen, berusia 38 tahun, mengajar di sini sudah 7 tahun, berstatus honorer, hanya mengajar di sekolah ini, belum mendapatkan sertifikasi guru. Darwin lulusan FKIP, berusia 36 tahun, mengajar disini sudah 6 tahun, pegawai negeri sipil Kemenag, juga mengajar di sekolah lain. Jerlina lulusan Pendidikan Agama Kristen Sekolah Tinggi Agama Kristen Tarutung, berusia 27 tahun, mengajar di sini sudah 3 tahun, sebagai pegawai honorer, juga mengajar di sekolah lain.

Guru Pendidikan Agama Katholik di sekolah ini berjumlah tiga orang yakni Agustinus Supriyanto S. Ag., Shito Mulyatidani S.Pd. M. Th., dan Andreas Yudho Astono S. Fil. Agustinus lulusan S1 Katekatik, berusia 54 tahun, mengajar di sini sudah 18 tahun, berstatus honorer (guru tidak tetap yayasan), hanya mengajar di sekolah ini, belum mendapatkan sertifikasi guru. Shito lulusan S2 Fakultas Teologi Weda Bakti Yogyakarta, berusia 43 tahun, mengajar disini baru satu tahun, pegawai honorer (guru tidak tetap yayasan), juga mengajar di sekolah lain. Andreas lulusan Jurusan Agama Fakultas Filsafat, berusia 39 tahun, mengajar di sini sudah 10 tahun, sebagai pegawai honorer (guru tidak tetap yayasan), tidak mengajar di sekolah lain.

Guru Pendidikan Agama Buddha di sekolah ini berjumlah tiga orang yakni Emilia Sari S. Ag., Eka Budi Susanto, S. Ag., dan Nuning Sihmiati S. Ag. Emilia lulusan S1 Pendidikan Agama Buddha, berusia 30 tahun, mengajar di sini baru satu tahun, berstatus honorer (guru tidak tetap yayasan), hanya mengajar di sekolah ini, belum mendapatkan sertifikasi guru. Eka lulusan S1 Dharma Duta Jakarta, berusia 34 
tahun, mengajar disini sudah tiga tahun, pegawai honorer (guru tidak tetap yayasan), tidak mengajar di sekolah lain. Nuning lulusan Pendidikan Agama Buddha, berusia 34 tahun, mengajar baru setengah tahun, sebagai pegawai honorer (guru tidak tetap yayasan), tidak mengajar di sekolah lain.

Dalam hal kurikulum pendidikan agama, SMK Bakti sampai saat ini masih menggunakan Kurikulum yang lama, yakni kurikulum tahun 2006 atau yang dikenal dengan KTSP (Kurikulum Tingkat Satuan Pendidikan). Sedangkan Kurikulum 2013 belum diterapkan. Walaupun demikian, pihak sekolah maupun sebagian guru di sekolah ini pernah memperoleh informasi mengenai Kurikulum 2013.

Dari segi materi pembelajaran, Pendidikan Agama Islam di SMK Bakti Pangkalpinang dilaksanakan berdasar Standar Kompetensi dan Kompetensi Dasar Pendidikan Agama Islam (SKKD) yang ada. Hanya variasinya, mungkin, ada yang berbeda dengan sekolah atau bahkan guru Pendidikan Agama Islam yang lain. Pendidikan Agama Islam tersebut diajarkan baik melalui intrakurikuler, co-kurikuler maupun ekstrakurikuler di kelas maupun di tempat lainnya di luar kelas. ${ }^{21}$

Kegiatan intrakurikuler dilaksanakan sesuai jadwal yang telah ditetapkan dan diberikan setiap semester dengan pola penjadwalan yang sama dengan mata pelajaran lainnya di luar pendidikan agama. Di sekolah ini, Pendidikan Agama Islam diberikan sebanyak dua kali dalam seminggu. Masing-masing jam pelajaran diberikan sebanyak 40 menit. Untuk efektifitas dan

${ }^{21}$ Wawancara dengan Drs. Ibrahim Sani, Guru Pendidikan Agama Islam, tanggal 23 April 2015. efisiensinya, Pendidikan Agama Islam di kelas tertentu diberikan dalam dua jam pelajaran secara berurutan.

Sebagai bagian kegiatan co-kurikuler, peserta didik juga diberi Pendidikan Agama Islam di luar kelas, tetapi tetap di dalam kompleks sekolah. Pendidikan seperti ini biasanya diberikan pada materi yang berkaitan dengan praktek seperti praktek salat, wudlu, dan haji. Praktek tersebut dilaksankan di musala milik Yayasan yang terletak di lantai 2 gedung sekolah ini. Luas musala ini 4 x 4 meter, yang disamping digunakan untuk praktik keagamaan Islam bagi peserta didik, juga untuk secara rutin dan bergiliran untuk kegiatan pengajian sekaligus arisan.

Kegiatan ekstrakurikuler Pendidikan Agama Islam juga sering diadakan di sekolah ini. Kegiatan tersebut diadakan antara lain bersamaan dengan hari besar Islam seperti Hari Raya Idul Adha, Isrok Mikroj, berbuka puasa bersama dan lain sebagainya. Hari Raya Qurban dilaksanakan dengan melakukan penyembelihan hewan kurban yang berasal dari stakeholder sekolah seperti tenaga pendidik dan kependidikan serta peserta didik. Isrok Mikroj dilaksanakan dilaksanakan oleh peserta didik muslim dan dibantu oleh tenaga kependidikan lainnya, bahkan dari peserta didik nonmuslim. Pada acara tersebut diundang penceramah yang berasal dari mubaligh wilayah ini. Buka puasa bersama dilakukan dengan mengundang peserta didik dan stakeholder lainnya yang beragama Islam serta dibantu penyelenggaraannya oleh peserta didik nonmuslim. Sebelum berbuka terlebih dahulu diadakan pengajian yang diberikan oleh penceramah. 
Adapun pembelajaran Pendidikan Agama Kristen, Pendidikan Agama Katholik, Pendidikan Agama Buddha di SMK Bakti Pangkalpinang dilaksanakan berdasar Standar Kompetensi dan Kompetensi Dasar (SKKD) Pendidikan Agama yang ada, diajarkan baik melalui intrakurikuler, cokurikuler maupun ekstrakurikuler di kelas maupun di tempat lainnya di luar kelas. Pendidikan Agama Kristen, Pendidikan Agama Katholik, Pendidikan Agama Buddha di sekolah ini dilaksanakan setiap Jumat siang, dengan jadwal waktu yang sama dengan kelas berbeda, yakni mulai pukul 11.05 - 12.25 untuk dua jam pelajaran secara berurutan.

Jauh hari sebelum mengajar, masingmasing guru agama membuat RPP terlebih dahulu, secara rapih dengan memperhitungkan berbagai aspek pembelajaran. Dalam melaksanakan pembelajaran di kelas, dengan mengacu RPP yang telah dibuat, dimulai dengan pembukaan, kemudian disampaikan secara selintas pelajaran sebelumnya, dilanjutkan dengan pemberian materi inti. Setelah itu dilakukan tanya jawab selintas dan di bagian akhir kegiatan adalah penutup. Untuk beberapa materi tertentu peserta diberi tugas mengerjakan di luar jam pelajaran dan diserahkan pada hari yang lain. Pola ini hampir sama antar guru Pendidikan Agama Kristen, Pendidikan Agama Katholik, Pendidikan Agama Buddha.

Kegiatan ekstrakurikuler Pendidikan Agama Kristen, Pendidikan Agama Katholik, Pendidikan Agama Buddha juga sering dilakukan oleh peserta didik sekolah ini. Kegiatannya dilaksanakan di luar sekolah yang lokasinya berbeda-beda, ada yang dilaksanakan di tempat ibadah dan ada yang dilaksanakan di tempat/gedung pertemuan.
Biasanya kegiatan tersebut dikaitkan dengan hari besar keagamaan masingmasing agama.

Kegiatan ekstrakurikuler Pendidikan Agama Kristen dan Pendidikan Agama Katholik dikaitkan dengan perayaan hari besar agama seperti hari natal dan paskah. Di samping itu peserta didik juga diajak untuk melakukan retreat bersama. ${ }^{22}$ Untuk kegiatan terkait dengan natal dan paskah dilakukan bersama dengan peserta didik sekolah lanjutan lainnya yang ada di Kota Pangkalpinang. Lokasi kegiatannya kadangkadang di Gereja masing-masing agama Kristen dan Katholik, dan kadang-kadang dilaksanakan di gedung pertemuan. Adapun retreat dilaksanakan di sekolah ini, yang biasanya, menjelang pelaksanaan ujian nasional (UN). Acara ini dipimpin oleh Guru Agama masing-masing. ${ }^{23}$

Kegiatan ekstrakurikuler Pendidikan Agama Buddha juga dikaitkan dengan perayaan hari besar agama Buddha, khususnya berkaitan dengan Perayaan Waisak. Untuk kegiatan seperti ini, dilakukan bersama dengan peserta didik sekolah lanjutan lainnya yang ada di Kota Pangkalpinang. Lokasi kegiatannya kadangkadang, biasanya, dilaksanakan di gedung pertemuan. ${ }^{24}$

Di SMK Bakti Pangkalpinang Pendidikan Agama Hindu dan Konghucu tidak diajarkan. Oleh karena itu, para peserta didik

${ }^{22}$ Wawancara dengan Darwin Purba S. Pd., Guru Pendidikan Agama Kristen. Tanggal 24 April 2015.

${ }^{23}$ Wawancara dengan Agustinus Supriyanto, S. Ag., Shito Mulyatidani S. Pd. M. Th., dan Andreas Yudho Astono S. Fil. Guru Pendidikan Agama Katholik. 25 April 2015.

${ }^{24}$ Wawancara dengan Eka Budi Susanto S. Ag. Guru Pendidikan Agama Buddha, tanggal 26 April 2015. 
mencari jalan lain untuk memperoleh nilai Pendidikan Agama di Rapor peserta didik masing-masing. Bahkan kadang-kadang mereka memilih salah satu Pendidikan Agama yang diajarkan di SMK ini. Mereka juga sering belajar sesuai agama yang dipeluk di luar kompleks sekolah.

Untuk peserta didik beragama Hindu, yang tahun ini ada satu orang, belajar agama Hindu kepada tokoh agama Hindu sesekali saja. Pimpinan sekolah juga telah menganjurkan untuk belajar ke tokoh agama Hindu yang ada di salah satu Pura di Pangkalpinang secara rutin. Namun kadangkadang ia juga mengikuti Pendidikan Agama Buddha. Hal ini ia jalankan karena alasan kepraktisan. Misalnya dengan ikut belajar Pendidikan Agama Buddha di sekolah, tidak diperlukan waktu yang khusus dan bisa belajar bersama dengan banyak teman-temannya ketika berlangsung pembelajarannya. Di samping itu, kata dia, pada dasarnya semua agama adalah mengajarkan kebaikan. ${ }^{25}$

Untuk peserta didik yang beragama Konghucu, saat ini umumnya mereka mengikuti Pendidikan Agama Katholik. Sebagian lainnya mengikuti Pendidikan Agama Buddha. Menurut sebagian mereka, alasan untuk tidak mengikuti Pendidikan Agama Konghucu karena di sekolah ini tidak ada Pendidikan Agama Konghucu. Sedangkan alasan mereka untuk memilih Pendidikan Agama Katholik adalah karena ketika masih di SMP, mereka belajar Pendidikan Agama Katholik. Jadi bagi mereka tidak ada masalah dengan belajar seperti ini. ${ }^{26}$ Nilai Rapor Pendidikan Agama

${ }^{25}$ Wawancara dengan AA Gede Putra Wedanto, siswa SMK Bakti, tanggal 26 April 2015.

${ }^{26}$ Wawancara dengan Januar Teriman dan Vebi L, Anggota Yayasan Bakti), tanggal 27 April 2015. mereka adalah Pendidikan Agama Katholik. Mereka belajar agama Konghucu kepada tokoh agama mereka dilakukan sesekali saja. Pihak sekolah juga telah pernah menganjurkan untuk belajar pendidikan agama sesuai agama mereka. Namun mereka tetap memilih Pendidikan Agama seperti saat ini.

Menurut Suryanto Candra, ${ }^{27}$ memang di Kota Pangkalpinang, khususnya di SMK Bakti belum diadakan Pendidikan Agama Konghucu secara khusus. Hal ini disebabkan masih terbatasnya guru yang telah memenuhi persyaratan untuk menjadi pendidikan agama. Diantaranya adalah persyaratan pendidikan minimal S1. Saat ini belum ada guru yang dimaksud.

Namun demikian, di SMK Bakti setiap tahun dilaksanakan perayaan hari besar atau tahun baru Imlek. ${ }^{28}$ Perayaan ini dihadiri oleh semua siswa. Pada kegiatan ini di samping ada acara doa bersama juga diadakan berbagai kegiatan lain, seperti pasar murah, mode show, lomba menyanyi dan lain sebagainya. Pada acara tersebut juga disajikan berbagai makanan khas Pangkalpinang yang sebagiannya dibawa oleh peserta didik.

\section{Sarana dan Prasarana Pembelajaran}

Sarana dan prasarana pembelajaran kali ini difokuskan kepada buku dan media pembelajaran serta kepustakaan. Secara umum, buku pelajaran yang menjadi bahan belajar Pendidikan Agama diperoleh dengan membeli sendiri atau meminjam, baik dari guru maupun peserta didik. Memang di

${ }^{27}$ Wawancara dengan Suryanto Candra, Ketua Matakin Provinsi Babel, tanggal 27 April 2015.

${ }^{28}$ Wawancara dengan Yanuar Teriman Teriman B. Sc. Anggota Yayasan Bakti, tanggal 27 April 2015. 
sekolah ini ada perpustakaan, namun untuk buku pendidikan agama masih kurang memadai tingkat ketersediaannya. Hanya ada sekitar 10 buku Pendidikan Agama. Sehingga jumlahnya masih sangat kurang dibandingkan dengan jumlah peserta didik masing-masing agama. Berkenaan dengan media pembelajaran, untuk Pendidikan Agama juga telah disediakan infocus.

Untuk Pendidikan Agama Islam, buku yang menjadi pegangan mereka diperoleh dengan cara membeli sendiri. Buku yang diapakai biasanya adalah "Pendidikan Agama Islam untuk SMA" yang diterbitkan oleh CV. Kharisma. Peserta didik membeli buku sendiri-sendiri. Memang di perpustakaan ada buku pegangannya, namun jumlah masih kurang. Kadang-kadang juga peserta didik diminta membaca Al Qur'an dengan membuka ayat-ayat tertentu. Tempat ibadah di sekolah ini berupa satu musala yang terletak di lantai 2 dengan ukuran $4 \mathrm{x}$ 4 meter.

Untuk Pendidikan Agama Kristen, ada beberapa buku yang menjadi pegangan guru diantaranya "Teladan Kehidupan", ditulis oleh Pdt. JG Engel, "Sahabat Kehidupan”, ditulis oleh Pdt. Deni, dan Al Kitab. Semuanya diadakan oleh para guru sendiri. Di samping itu Al Kitabpun juga menjadi pegangan utama dalam proses pembelajarannya. Untuk peserta didik, sebagiannya mendapat buku dengan judul "Suluh Siswa". Sebagian mereka juga memiliki buku agama yang menjadi pegangan guru. Di sekolah ini tidak ada tempat ibadah secara khusus bagi pemeluk Kristen. Bila dilakukan praktik keagamaan sebagai bagian dari pelajaran maka dilaksanakan di ruang kelas. Akan tetapi apabila dilakukan ibadah dengan melibatkan banyak orang maka dilaksanakan di gereja atau di gedung pertemuan.
Untuk Pendidikan Agama Katholik, buku yang mejadi pegangan guru antara lain "Pendidikan Agama Katholik: Menjadi Murid Yesus”, ditulis oleh Yosep Kartono, penerbit Kanisius, dan "Perutusan Muridmurid Yesus" terbitan Komisi Katekatik. Semuanya hasil "pengadaan" guru sendiri, seperti meminjam dan membeli. Peserta didik sebagiannya membeli sendiri, dan lainnya meminjam buku yang ada di perpustakaan, walupun masih kurang jumlahnya. Untuk media pembelajarannya, kadang-kadang digunakan lap top, infocus, atau LCD. Di sekolah ini juga tidak ada tempat ibadah secara khusus untuk pemeluk agama ini.. Sehingga kalau praktik sebagai bagian dari pelajaran maka dilaksanakan di ruang kelas. Akan tetapi apabila dilakukan ibadah dengan melibatkan banyak orang maka dilaksanakan di gereja atau di gedung pertemuan.

Untuk Pendidikan Agama Buddha, buku yang menjadi pegangan guru terutama "Pendidikan Agama Buddha Untuk SMA", ditulis oleh Mujiyanto, penerbit Paramita Surabaya. Buku tersebut diadakan oleh para guru sendiri. Untuk peserta didik, sebagiannya mendapat buku dengan judul "Suluh Siswa". Sebagian mereka juga yang memiliki buku agama yang menjadi pegangan guru. Di sekolah ini tidak ada tempat ibadah secara khusus untuk agama ini. Sehingga kalau praktik sebagai bagian dari pelajaran maka dilaksanakan di ruang kelas. Akan tetapi apabila dilakukan ibadah dengan melibatkan banyak orang maka dilaksanakan di Vihara.

Evaluasi Pendidikan Agama Islam terhadap para peserta didik dilihat dari tiga ranah yakni kognitif, afektif, dan psikomotorik. Semua nilai akhir dimasukkan dalam buku Rapor Sekolah yang dimiliki 
oleh masing-masing peserta didik. Nilai Rapor tersebut merupakan akumulasi dari nilai ulangan harian, semesteran, sampai ulangan akhir tahun dan ujian akhir sekolah. Semuanya dilaksanakan oleh guru yang bersangkutan. Dalam prosesnya guru yang bersangkutan memperoleh masukan dari guru yang lain dan pihak-pihak lainnya khususnya jajaran Pimpinan sekolah.

Semua nilai di berbagai kesempatan tersebut, dalam prosesnya, dicatat dalam lembar atau buku daftar nilai ulangan dan pengamatan guru terhadap masingmasing peserta didik. Catatan nilai tersebut dikelompokkan dalam 3 ranah tadi yakni kognitif, afektif dan psikomorotik. Nilai akhir ditulis dalam bentuk hitungan angka antara 0 sampai 100.

Evaluasi juga dilakukan terhadap Pendidikan Agama Kristen, Pendidikan Agama Katholik, Pendidikan Agama Buddha oleh masing-masing guru. Evaluasinya dilihat dalam berbagai ranah yang ada, yakni kognitif, afektif, psikomotorik dan dilakukan beberapa kali. Teknik evaluasinya ada yang berbentuk tes kognitif secara lesan dan tertulis serta ada yang berbentuk praktik dan pengamatan. Dari segi waktu, evaluasinya antara lain dilakukan setelah mata pelajaran selesai atau yang dikenal dengan ulangan harian. Evaluasi lainnya diberikan pada setiap semester dan menjelang kenaikan kelas ujian akhir sekolah.

Untuk evaluasi harian yang terkait dengan kognisi atau pengetahuan dilakukan dengan tes lesan. Untuk yang terkait dengan aspek lainnya diberikan dalam praktik di depan kelas. Untuk evaluasi yang terkait dengan perilaku dan kebiasaan sehari-hari sesuaidengan standarkompetensi, dilakukan secara berkala dan terus menerus. Semua nilai dari evaluasi tersebut dimasukkan dalam Rapor milik masing-masing peserta didik yang dirangkum pada tiga ranah yakni ranah kognitif, psikomotorik, dan afektif. Dengan demikian nilai Rapor Pendidikan agama berasal dari kumpulan nilai berbagai evaluasi tersebut.

\section{Kebijakan Khusus Pelayanan Pendidikan Agama}

Kebijakan layanan Pendidikan Agama di SMK Bakti Pangkalpinang pada dasarnya mengikuti Peraturan yang ada, mulai dari Undang-Undang Dasar 1945, UndangUndang Nomor tahun 2003 tentang Sistem Pendidikan Nasional dan berbagai Peraturan lainnya. Pihak Yayasan Bakti yang menjadi penaung dan pendirinya berusaha menjalankansegalaPeraturanterkaitdengan Pendidikan Agama di sekolah. Walaupun pihak Yayasan memaklumi bahwa hal itu membawa konsekuensi penambahan guru dan hal yang terkait dengannya. Pendidikan Agama Islam, Kristen, Katholik, dan Buddha yang diadakan saat ini merupakan wujud dari kebijakan pihak Yayasan dan sekolah yang berusaha memenuhi berbagai peraturan yang ada. Hanya, urusan lebih teknis operasional seperti penjadwalan dan lain sebagainya diserahkan kepada pihak sekolah. Sedangkan Yayasan tidak terlibat terlalu dalam/banyak.

Pengadaan calon guru Pendidikan Agama diseleksi oleh Sekolah. Dalam hal pengadaannya, prinsip utama pihak dari sekolah adalah calon guru tersebut bukan hanya memiliki pengetahuan di bidangnya saja, akan tetapi juga memiliki akhlak, budi 
pekerti dan perilaku yang baik dan layak untuk diteladani. ${ }^{29}$

Untuk rekrutmen guru pendidikan agama di SMK Bakti, dimulai dari informasi atau pengumuman bahwa di sekolah ini membutuhkan tenaga pendidik. Informasi atau pengumuman secara terbatas. Calon guru yang berminat kemudian mengajukan lamaran sesuai ketentuan. Khusus untuk guru Pendidikan Agama Katholik, maka rekrutmennya berasal dari Gereja, bukan dari guru yang bersangkutan. Artinya, guru harus mendapat persetujuan lebih dahulu.

KementerianAgamaKotaPangkalpinang, sebagai pembina Pendidikan Agama di sekolah, dan juga Pemerintah Daerah Kota Pangkalpinang, sudah beberapa tahun ini tidak menerima pegawai negeri baru yang diangkat menjadi guru pendidikan agama. Menurut Kepala Kantor Kementerian Agama kota Pangkalpinang, sudah lebih dari 5 tahun tidak pernah menerima pegawai baru. Memang pada tahun 2014 yang lalu, Kantor ini menerima CPNS sebanyak 20 orang. Namun di antara mereka tidak ada yang dicalonkan menjadi guru pendidikan agama. ${ }^{30}$

Menurut Kakankemenag, hak menerima guru di sekolah, termasuk pengadaan/ penerimaan guru pendidikan agama di sekolah, adalah kewenangan Pemerintah Daerah Kota Pangkalpinang. Namun sampai saat ini Pemda belum pernah mengadakan hal itu. Tahun 2014 yang lalu, Pemda Kota Pangkalpinang menerima sekitar 90 CPNS. Tidak ada alokasi untuk guru pendidikan

\footnotetext{
${ }^{29}$ Wawancara dengan Hastin Lusiana Todhasi SE, Kepala Sekolah SMK Bakti Pangkalpinang, tanggal 23 April 2015.

${ }^{30}$ Wawancara dengan Drs. H. Paidi, Kepala Kantor Kementerian Agama Kota Pangkalpinang, tanggal 23 April 2015.
}

agama. Sebagian besar adalah untuk tenaga administrasi, sebagian kecil lainnya untuk guru SD.

Terdapat sejumlah faktor pendukung dan penghambat bagi terrealisirnya layanan pendidikan agama di SMK Bakti Kota Pangkalpinang. Berikut disajikan sejumlah faktor pendukung dan penghambatnya.

Faktor pendukung utamanya adalah bahwa pihak Yayasan dan SMK Bakti memberikan kesempatan untuk melaksanakan Pendidikan Agama, baik Islam, Kristen, Katholik maupun Buddha dengan menyediakan jumlah guru yang cukup. Dukungan yang sama juga diberikan oleh Kementerian Agama melalui Pengawas dan Pembimas. Faktor pendukung lainnya, khusus bagi Pendidikan Agama Islam, adalah adanya musala yang dapat digunakan untuk meningkatkan kualitas pelayanan Pendidikan Agama Islam, melalui praktik ibadah dan pengajian. Adanya peralatan semacam infocus dan yang semisalnya juga merupakan dukungan yang penting. Peserta didik juga secara umum sangat aktif dan responsif terhadap Pendidikan Agama.

Terdapat sejumlah faktor penghambat, antara lain berkaitan dengan sarana dan prasarana seperti kurangnya jumlah buku yang memadai bagi peserta didik untuk semua agama. Pelajaran Pendidikan Agama Islam memang telah memiliki musala, akan tetapi dirasakan masih terlalu sempit sehingga kurang mencukupi untuk praktik ibadah dan kegiatan keislaman lainnya.

Dalam hal jadwal pelajaran, selain Pendidikan Agama Islam, dibuat atau diletakkan pada jam yang sama untuk semua kelas, walaupun peserta didiknya relatif banyak dan diberikan di luar jadwal yang formal. Hal ini sering menyebabkan kesulitan dalam mengatur kelas dan tenaga 
pengajarnya karena diberikan dalam waktu yang bersamaan. Waktunyanyapun ditempatkan pada siang hari, sehingga kurang kondisuf suasananya.

Dalam hal evaluasi yang mencakup ranah kognitif, afektif, dan psikomotorik maka dirasakan adanya kesulitan ketika menilai aspek afektif dan psikomotorik. Idealnya, aspek-aspek tersebut sangat banyak akan tetapi tidak atau belum ada petunjuk operasional yang secara mudah diterapkan di lapangan. Dari uraian di atas terlihat bahwa SMK Bakti telah menerapkan sejumlah peraturan yang berkaitan dengan Pendidikan Agama di sekolah. Namun terdapat sejumlah kecil lainnya yang belum diterapkan karena alasan tertentu. Pendidikan Agama di Sekolah ini telah diimplementasikan untuk memberikan pengetahuan dan membentuk sikap, kepribadian dan keterampilan peserta didik dalam mengamalkan ajaran agama, yang dilaksanakan sekurang-kurangnya melalui mata pelajaran pada semua jalur, jenjang, dan jenis pendidikan. Pendidikan Agama di SMK berbentuk proses pembelajaran di sekolah baik yang intra maupun yang ekstrakurikuler.

Ini berarti Sekolah ini telah menerapkan sebagian besar sejumlah ketentun yang ada. Undang-Undang Sistem Pendidikan Nasional Nomor 20 tahun 2003, khususnya Pasal 12 ayat 1.a Undang-undang No 20 tahun 2003 tentang Sistem Pendidikan Nasional, disebutkan bahwa "Peserta didik pada setiap satuan pendidikan berhak mendapatkan pendidikan agama sesuai agama yang dianutnya", telah diimplemetasikan di sekolah ini.

Pendidikan Agama di Sekolah ini juga merupakan pelaksanaan dari sejumlah peraturan mengenai hak asasi manusia.
Kebebasan beragama merupakan salah satu hak dasar yang melekat pada setiap orang. Dalam deklarasi Universal tentang HAM yang diadopsi PBB tahun 1948, antara lain disebutkan bahwa setiap orang mempunyai hak kebebasan berpikir, berkesadaran, dan beragama, termasuk kebebasan memilih dan memeluk agama, dan menyatakan agamanya itu dalam pengajaran, pengamalan, dan beribadatnya, baik secara sendiri-sendiri maupun dalam kelompok.ini juga berarti bahwa implementasi Pendidikan Agama di Sekolah ini merupakan penghormatan kebebasan orang tua dan wali untuk memastikan bahwa pendidikan agama dan moral anak-anak sesuai dengan keyakinan mereka. Undang-Undang Perlindungan Anak Nomor 23 Tahun 2002 pun juga telah diimplementasikan. Di dalamnya antara lain disebutkan bahwa : (1) setiap anak mendapat perlindungan untuk beribadah menurut agamanya, (2) Sebelum anak dapat menentukan pilihannya, agama yang dipeluk anak mengikuti agama orang tuanya. Negara, pemerintah, masyarakat, keluarga, orang tua, wali, dan lembaga sosial menjamin perlindungan anak dalam memeluk agamanya, perlindungan anak dalam memeluk agamanya sebagaimana dimaksud meliputi pembinaan, pembimbingan, dan pengamalan ajaran agama bagi anak.

Namun mesti diakui bahwa terdapat sebagian Pendidikan Agama belum terlaksana di Sekolah ini. Pendidikan Agama Khonghucu belum terlaksana. Pada hal peserta didiknya cukup banyak. Mengacu kepada Keputusan Menteri Agama Nomor 6 Tahun 2010 tentang Pengelolalaan Pendidikan Agama pada Sekolah, Pendidikaan Agama Khonghucu mesti dilaksanakan. Pada Pasal 3, secara eksplisit dinyatakan bahwa setiap sekolah 
berkewajiban menyediakan pelajaran agama kepada siswa, dan diajarkan oleh guru yang seagama dengan siswa. Selanjutnya dalam Pasal 4 dinyatakan ketentuan teknis tentang pelajaran agama di kelas atau sekolah, sebagai berikut: dalam hal jumlah peserta didik yang seagama dalam satu kelas paling sedikit 15 (lima belas) orang wajib diberikan pendidikan agama kepada peserta didik di kelas. Dalam hal jumlah peserta didik yang seagama dalam satu kelas kurang dari 15 (lima belas) orang, tetapi dengan cara penggabungan beberapa kelas paralel mencapai paling sedikit 15 (lima belas) orang, maka pendidikan agama pada sekolah dilaksanakan dengan mengatur jadwal tersendiri yang tidak merugikan siswa untuk mengikuti mata pelajaran lain. Dalam jumlah peserta didik yang seagama pada satu sekolah kurang dari 15 (lima belas) orang, maka pendidikan agama dilaksanakan bekerja sama dengan sekolah lain, atau lembaga keagamaan yang ada di wilayahnya.

\section{PENUTUP}

SMK Bakti Pangkalpinang Provinsi Kepulauan Riau terdapat 657 peserta didik, terdiri dari pemeluk agama Buddha berjumlah 233 orang (35,46\%), Konghucu 130 (19,79\%), Kristen 114 orang (17,35 $\%)$, Katholik 103 orang ( 15,68\%), Islam 76 orang $(11,56 \%)$ dan pemeluk agama Hindu satu orang ( 0,15\%). Guru pendidikan agama di sekolah ini berjumlah 11 orang, terdiri dari masing-masing 3 guru Pendidikan Agama Kristen, guru Pendidikan Agama Katholik, guru Pendidikan Agama Buddha, serta 2 guru Pendidikan Agama Islam. Tidak terdapat guru pendidikan agama Konghucu dan Hindu di sekolah ini.

Pendidikan Agama Buddha, Kristen, Katholik, danPendidikan AgamaIslam diSMK Bakti Pangkalpinang diimplementasikan secara sistematis dan terstruktur. Artinya Pendidikan Agama dilaksanakan pada jam sekolah sebanyak masing-masing dua jam satu minggu, dan diajar sesuai guru dan agama peserta didik, serta dievaluasi sesuai ketentuan yang ada. Pendidikan Agama Buddha, Kristen, Katholik, dan Islam pun juga diberikan melalui kegiatan ekstrakurikuler. Sejumlah sarana dan prasarana Pendidikan Agama Pendidikan Agama Buddha, Kristen, Katholik, dan Islam telah terdapat di SMK Bakti, seperti buku pelajaran, dan perlengkapan tekonologi informasi. Khusus tempat ibadah untuk latihan praktik Pendidikan Agama Islam berupa musala telah terdapat di Sekolah ini, sedangkan tempat ibadah agama lainnya belum tersedia. Sementara itu, Pendidikan Agama Hindu dilaksanakan di tempat ibadah agama Hindu (Pura) yang berada di luar kompleks sekolah, dan diajar oleh guru yang beragama Hindu.

Pendidikan Agama Konghucu belum diimplementasikan di SMK Bakti. Pada hal, jumlah peserta didik beragama Khonghucu relatif banyak yakni 130 anak, atau nomor urut dua bila dilihat dari segi jumlahnya. Hal ini dikarenakan belum adanya guru Pendidikan Agama Khonghucu yang telah memenuhi syarat untuk mengajar di sekolah ini. Karena tidak ada Pendidikan Agama Khonghucu, maka berbagai standar pendidikannya juga belum ada. Peserta didik yang beragama Konghucu mengikuti Pendidikan Agama Katolik dan Buddha dengan sukarela. 
Faktor pendukung terimplemetasikannya Pendidikan Agama di SMK Bakti adalah pemberian kesempatan luas pihak Yayasan dan SMK Bakti untuk melaksanakan Pendidikan Agama dengan fasilitas sesuai dengan kemampuannya. Dukungan yang sama juga diberikan oleh Kementerian Agama melalui Pengawas dan Pembimas. Faktor penghambat, antara lain masih minimnya sarana dan prasarana yang memungkinkannya implementasi Pendidikan Agama di sekolah ini secaara maksimal.

Saran dari studi ini adalah : pertama, Walaupun sejumlah standar Pendidikan Agama Buddha, Kristen, Katholik, dan Pendidikan Agama Islam di SMK Bakti Pangkalpinang diimplementasikan, peningkatan kualitaas dan kuantitasnya tetap diperlukan, seperti pengadaan tempat ibadah dan bahan ajar bagi masing-masing agama. Tempat ibadah tersebut tidak perlu mengambil tempat yang luas, akan tetapi dengan memanfaatkan ruang yang ada secara maksimal. Buku-buku yang diperlukan di samping buku yang jadi bahan pembelajaran di kelas, juga untuk bahan pengayaan baik bagi guru maupun peserta didik.

Kedua, Pendidikan Agama Konghucu perlu diimplementasikan di SMK Bakti mengingat jumlah peserta didikya telah lebih dari 15 (lima belas) orang. Sejumlah landasan perundangan telah ada yang menjadi dasar implementasi tersebut; seperti Undang-undang nomor 20 tahun 2003 tentang Sisdiknas, khususnya Pasal 12 ayat 1.a; Peraturan Pemerintah nomor 55 tahun 2007 tentang Pendidikan Agama dan Keagamaan; Keputusan Menteri Agama Nomor 6 Tahun 2010 tentang Pengelolalaan Pendidikan Agama pada Sekolah.
Ketiga, Karena sebagian persyaratan untuk menjadi guru Pendidikan Agama Konghucu belum terpenuhi, khususnya persyaratan latar belakang pendidikan minimal sarjana Strata 1 (satu), maka disarankan kepada Kementerian Agama dan Pemerintah Daerah untuk mencetak guru Pendidikan Agama Konghucu yang sesuai dengan peraturan yang ada.

Keempat, Agar implementasi Pendidikan Agama di SMK Bakti dapat terlaksana secara maksimal maka perlu ditingkatkan kordinasi dengan Kementerian Agama, Pemerintah Daerah, dan Majlis-majlis Agama yang ada di Kota Pangkalpinang khususnya, dan Provisi Kepulauan Bangka Belitung pada umumnya.

\section{UCAPAN TERIMA KASIH}

Penulis mengucapkan banyak Kepada Puslitbang Pendidikan Agama dan Keagamaan atas pemberian kesempatan kepada penulis untuk melaksanakan penelitian ini yang dibiayai oleh anggaran belanjanegaramelaluiPuslitbangPendidikan Agama dan Keagamaan. Penulis juga mengucapkan terima kasih atas bantuan dan masukan yang berasal dari Kepala dan para peneliti dari Puslitbang Pendidikan Agama dan Keagamaan, khususnya Dr. Hayadin, sehingga tulisan ini dapat tersaji, yang sebelumnya telah diseminarkan di hadapan akademisi, peneliti, guru pendidkan Agama, dan pejabat teknis bidang pendidikan Agama.

\section{DAFTAR PUSTAKA}

Bagir, Haidar. (2003): “Gagalnya Pendidikan Agama”, Harian Kompas, Jum'at 28 Februari 2003. 
Direktur Jenderal Kelembagaan Agama Islam. (2002): Buku Kebijakan Direktur Jenderal Kelembagaan Agama Islam di Bidang Pendidikan Agama dan Keagamaan Islam. Jakarta; Direktur Jenderal Kelembagaan Agama Islam.

Fatah, Nanang. (2014): Analisis Kebijakan Pendidikan. Bandung; PT Remaja Rosdakarya.

Hasbullah, M. (2015): Kebijakan Pendidikan Dalam Perspektif Teori, Aplikasi, dan Kondisi Objektif Pendidikan di Inndonesia. Jakarta; PT Rajagrafindo.

Hornby, A.S. dkk. (1972): The Advance Learner's Dictionary of Current English. London; Oxford University Press. Seventh Impression.

Mahfudz, Sahal, K.H. Harian Kompas. (2003): "Pendidikan Agama di Sekolah Dinilai Gagal”. 31 Mei 2003.

Nugroho, Riant. (2013): Kebijakan Pendidikan Yang Unggul. Cetakan ke II. Yogyakarta; Pustaka Pelajar.

Nurudin. (2013): “Implementasi Kebijakan Pendidikan Agama Di Sekolah-Sekolah Katolik. Studi Kasus Kota Blitar Provinsi Jawa Timur". Edukasi. Jurnal Pendidikan Agama dan Keagamaan, 2013 (3), halaman 182 - 198.

Shaleh, Abdurrahman. (1999): Aktualisasi Politik Pendidikan di Lingkungan Departemen Agama. Jakarta; Badan Litbang Agama.

Sudjana, Nana. (1989): Penilaian Hasil Proses Belajar Mengajar. Bandung; Remaja Rosdakarya.

Suhadi dkk. (2014): Politik Pendidikan Agama, Kurikulum 2013, dan Ruang Publik Sekolah.
Yogyakarta: Center for Religious \& Cross-cultural Studies (CRCS). Sekolah Pascasarjana, Universitas Gadjah Mada.

Tholkhah, Imam. (2010): Rencana Strategis Direktorat Pendidikan Agama Islam Pada Sekolah Tahun 2010-2014. Jakarta; Direktorat Jenderal Pendidikan Islam Kementerian Agama RI.

Tholkhah, Imam. (2013): “Pendidikan Toleransi Keagamaan: Studi Kasus SMA Muhammadiyah Kupang Nusa Tenggara Timur". Edukasi. Jurnal Pendidikan Agama dan Keagamaan, 2013 (3), halaman 165 181.

Tim Penyusun. (1996): Departemen Agama Dari Masa Ke Masa Dalam Kurun Setengah Abad. Jakarta; Badan Litbang Agama.

Deklarasi Universal Hak Asasi Manusia. Diterima dan diumumkan oleh Majlis Umum PBB, tanggal 10 Desember 1948.

Keputusan Menteri Agama Nomor 6 Tahun 2010 tentang Pengelolalaan Pendidikan Agama pada Sekolah. Pada Pasal 3 dan 4.

Kovenan Internasional Hak-hak Ekonomi, Sosial, Budaya. Ditetapkan oleh Resolusi Majlis Umum PBB tertanggal 16 Desember 1966.

Peraturan Pemerintah Nomor 55 Tahun 2007 tentang Pendidikan Agama dan Keagamaan, Pasal 1 ayat 1 .

Undang-Undang Dasar Negara Republik Indonesia Tahun 1945, Bab XIII, Pasal 31 ayat $1,2,3$, dan 4 .

Undang-Undang Sistem Pendidikan Nasional Nomor 20 tahun 2003, Pasal 1 ayat 1.

Undang-Undang Perlindungan Anak Nomor 23 Tahun 2002. 